\title{
The Emergence and Expansion of the Permanent Diplomacy
}

\author{
Gökhan Erdem*
}

\begin{abstract}
Diplomacy was of an ad hoc character in Europe until the $15^{\text {th }}$ century. Permanent diplomacy emerged in a region of Italy in the $14^{\text {th }}$ century and then expanded to the rest of Europe. From the $16^{\text {th }}$ century onwards, imperial France advanced both the institutional and methodological practice of permanent, professional diplomacy. Later, during the $19^{\text {th }}$ century, permanent diplomatic practice became central to international relations, and still continues to be of vital service to the conduct of world affairs.
\end{abstract}

\section{Keywords}

Diplomacy, Permanent Diplomacy, Diplomatic History, Italy

* Gökhan Erdem, PhD, is a research fellow in the Department of International Relations, Ankara University, Ankara, Turkey. 


\section{Introduction}

Although the roots of diplomacy can be traced back to prehistoric times, it was not until the inception of settled life and the emergence of state structures that it took on a meaning close to its contemporary form. It is known that in ancient Mesopotamia, a system of states emerged which prompted the rapid evolution of diplomatic institutions and methods. ${ }^{1}$

Until the $15^{\text {th }}$ century, the practice of diplomacy in Europe was mostly ad hoc in character. Diplomatic missions were unilateral and temporary as evidenced by the limited, issue specific remits of ambassadors, who typically returned home on completion of their specific assignments. Their individual activities ranged from attending ceremonies, communicating declarations of war, negotiating peace treaties or relaying specific information. As such, these interactions did not necessitate institutional and professional practice, diplomatic corps and supporting organizations, or offices for permanent representatives in their host countries.

While the gradual transition to permanent diplomacy began in Europe in the $15^{\text {th }}$ century, informal practices continued in use until the $19^{\text {th }}$ century. This article analyzes the concept of permanent diplomacy, with a particular focus on the conditions of its emergence and pervasion in Europe.

\section{The Concept of Permanent Diplomacy}

Throughout the $15^{\text {th }}$ century diplomacy began to gain a permanent nature by losing its ad hoc character. Here, permanency relates to the management of diplomatic activities rather than the duration of relations among states. Prior to this, diplomatic

\footnotetext{
${ }^{1}$ See: Raymond Cohen, "The Great Tradition: The Spread of Diplomacy in the Ancient World", Diplomacy and Statecraft, Vol. 12, No. 1, (March 2001), pp. 23-38.
} 
The Emergence and Expansion of the Permanent Diplomacy

relations between two European states was maintained only for as long as there existed issues of mutual interest.

Diplomatic relations gained permanency through the institutionalization continuing diplomatic activities between states, primarily through diplomatic representative offices. In this new understanding, an embassy took the place of an ambassador who was sent for specific goals and for a specific period. With permanent diplomacy, the office comes before the individual; in other words, diplomatic representation comes before the diplomatic representative. ${ }^{2}$

As envisaged by Anderson "many of them [diplomats] remained in post at the court of some foreign ruler for a considerable time, transacting business and transmitting information over a period of at least months and often years". 3 This description considers the duration of a diplomatic mission as the most important determinant. However, what makes a diplomatic activity permanent is the quality of institutional support it receives, not necessarily its duration. In ancient Mesopotamia, there were examples of diplomatic missions that served for periods of 20 years or longer. ${ }^{4}$

Institutionalization arose in response to increasing difficulties in the practice of diplomatic activities, as well as demands for executing them to higher standards. As Queller highlights, the necessity to conduct diplomatic activities in a more costly and practical way played an important role in the adoption of permanent diplomacy. ${ }^{5}$

${ }^{2}$ Adam Watson, Diplomacy: The Dialogue between States, London, Routledge, 1982, pp. 100-101.

3 M. S. Anderson, The Rise of Modern Diplomacy: 1450-1919, New York and London, Longman, 1993, pp. 5-6.

${ }^{4}$ Bertrand Lafont, "International Relations in the Ancient Near East: The Birth of a Complete Diplomatic System", Diplomacy and Statecraft, Vol. 12, No. 1, (March 2001), p. 49.

5 Donald E. Queller, The Office of Ambassador in the Middle Ages, Princeton, Princeton University Press, 1967, p. 82. 
Modern diplomacy began to take shape in Italy and the factors that caused its emergence will be analyzed below. As such it was part of a general transformation in Europe that encompassed politics, culture, economics and religious beliefs. The transition to permanent diplomacy should therefore be analyzed as part of a larger framework and not solely in terms of the dynamics of $15^{\text {th }}$ century Italy. However, it is generally acknowledged that this new understanding of diplomacy was pioneered by Italian states of the time.

\section{Reasons for the Transition to Permanent Diplomacy}

\section{A) Political Factors}

\section{1) External Political Factors}

In early $14^{\text {th }}$ century, Europe was divided into different regional sub-systems that were independent from each other. Feudalism was losing ground and regional powerbases began to alter the role of traditional structures at the local level, so that they supported regional ambitions as part of a functional sub-system. As relations between units under a sub-system developed and became regular, intra-systemic relations intensified progressively. Italy, particularly northern Italy, went on to develop most of the systemic characteristics of these sub-systems. During the mid- $14^{\text {th }}$ century, the Italian peninsula was divided into small and wellorganized states. The most prominent of these were the Duchy of Milan, the Republic of Florence, the Kingdom of Naples, the State of the Papacy, the Republic of Venice, followed by Genoa and Montua.

\footnotetext{
${ }^{6}$ Anderson, The Rise of Modern Diplomacy, p. 2.
} 
The Emergence and Expansion of the Permanent Diplomacy

The location of this sub-system of Italian city-states seems to have played an important role. According to Mattingly, in the second half of the $14^{\text {th }}$ century and the $15^{\text {th }}$ century, the northern Italian region was "relatively isolated". 7 There were also many reasons for the Italian city-states to maintain their relations with each other while few of the big states of the period were able to exert considerable influence over this region. During this period Europe witnessed the collapse of the Byzantine Empire, the weakening of the Holy Roman Empire, the internal problems that France experienced due to the Hundred Years' War, and internal division within the Papacy over religious and political issues.

The isolation in question caused a contest for power between these regional states that lasted for a considerable period. While issues of trade and competition generated this conflict, it soon became a struggle for survival and domination. Conditions became such that the governors of these states were forced to guard against a wide range of external threats. Moreover, the ambiguity of the external conjecture was conducive in fostering internal problems. During this period in Italian political culture, there was a general belief that heads of state were besieged with existential issues and risked "constant enclosure". 8

As these city-states lacked sufficient power to sustain themselves on their own, they relied on alliances that would help to guarantee their existence. This in turn placed great importance on successful diplomacy.

Lack of confidence and continuous concern for external political balances forced the Italian city-states to monitor and obtain information about each other. Better knowledge of each other's capabilities and intentions enabled them to influence regional developments in their favor. However, the ultimate success or failure of their initiatives often depended on the

\footnotetext{
${ }^{7}$ Garrett Mattingly, Renaissance Diplomacy, 3. ed., London, Butler \& Tanner, 1963, p. 61.

${ }^{8}$ Ibid., p. 57.
} 
effective, rapid and organized conduct of diplomacy. These requirements stimulated the establishment of permanent diplomatic representative offices. By the middle of the $15^{\text {th }}$ century, the external powers started to become interested in the region again, and thus permanent diplomatic representative offices also began to be established outside the Italian sub-system. ${ }^{9}$

The balance of power among Italian city-states had to be continuously re-established because of the occurrence of quick shifts in these states. This situation played an important role in bringing permanency to diplomatic activities and in a way gave it a daily notion. As Nicholson emphasizes, "the situation of that contemporary threat gave rise to gain importance of actual negotiating art that would save the day instead of long term policies". ${ }^{10}$

The city-states proved that their relative lack of military and political power could be compensated for by their power of diplomacy. This dynamic took hold amongst city-states that did not practice a "universalist" political philosophy and expression contrary to the Roman tradition. Therefore, none of the Italian city-states refused the sovereign equality principle that was very important for the development of diplomacy's multilateral character.

\section{2) Internal Political Factors}

Significant socio-economic transformation had begun to influence the political arena in the Italian city-states. While the political form and the political philosophy of the dominant medieval system remained effective for a couple of centuries, it began to give way to a new organizational structure that promoted a different understanding of diplomacy and its organization.

\footnotetext{
9 Anderson, The Rise of Modern Diplomacy, p. 3.

10 Harold Nicholson, The Evolution of Diplomatic Method, London, Cassell Publishers, 1954, p. 31.
} 
The Emergence and Expansion of the Permanent Diplomacy

When the political organizational dimension is analyzed, the most general phenomenon that can be observed is that northern Italy was the first venue where feudalism disappeared in Europe. Here, the changing socio-economic dynamics gradually replaced the feudal organizational form with a more centralist one. Italian city-states were the first European political units to invest sovereign kings or governments with territorial authority. Therefore, the political, military, economic, legal authorization and privileges of the focuses of feudal power were passed to a central authority. This transfer of authority effectively terminated the structures and hence the operation of the feudal system. The traditional entities of the feudal system were replaced by a territorial and general legitimization that was vested in a central authority.

The small surface area of the Italian city-states, Venice being somewhat of an exception, made a positive contribution to the process of the centralization of authority. Here, central authorities could more effectively bring improvements in transportation, taxation and supervision. ${ }^{12}$ The growing effectiveness of these central authorities further eased the termination of the focuses of feudal power. If there had been significant feudal powers in Italy, as there were in Eastern and Central Europe, the central authorities of the city-states would have been opposed by them. Instead, the gradual transformation of power took over a century to be realized and did not require the development of significant military power.

The effects of this centralization process on foreign policy and diplomacy were several. Centralization played a great role in the development of permanent and regular affairs with other

\footnotetext{
${ }^{11}$ For detailed analysis of Feudalism, March Bloch, Feudal Society: Social Classes and Political Organization, translated by L. A. Manyon, London, Routledge and Kegan Paul, 1967. In addition, for the Collapse of feudalism and the emergence of centralization of state process, Norbert Elias, The Civilizing Process, translated by Edmund Jephcott, Oxford, Blackwell, 1994.

${ }^{12}$ Mattingly, Renaissance Diplomacy, p. 59.
} 
foreign political actors as well as the ability of alliance formation, issues which form the basis of foreign policy. ${ }^{13}$ First of all, with the onset of centralization, an effective and centralized state structure emerged, which also took foreign policy almost entirely under its control. Furthermore, centralization had distanced foreign policy from the effects of local power focuses and paved the way for a synchronized, coherent and territorial based foreign policy that was gathered in one hand.

Centralization of foreign policy brought about a shift in the institutional and methodological development of diplomacy. It secured the centralization of diplomatic affairs and the emergence of a bureaucratic structure in the institutional context. Thus, the establishment of permanent embassies was realized as a result of the bureaucratization that accompanied centralization. ${ }^{14}$ When the development of methodological dimension is taken into account, centralization led diplomacy to be subject to a single authority and secured a more synchronized and consistent pursuit of diplomacy, which in turn enhanced the opportunity for direct observation of territorial interests.

Italy can be seen as the first region of Medieval Europe where political philosophy shaped by feudalism and Christianity began to lose its effectiveness. The sovereign understanding of the Medieval Ages that political legitimization is dependent on Christianity and feudal rights and obligations continued to exert its effect on the Catholic world until the $14^{\text {th }}$ and $15^{\text {th }}$ centuries. According to this understanding, the state has basically a secondary role. Through the effects of Christianity, political authority gained a secondary position to religious authority. Individuals were encouraged to relate to the outside world according to the frame of Christian teaching. The spiritual world was held above the material world, itself the extension of the spiritual world created by God. The trivial of the material world refers to the trivial of the

\footnotetext{
13 Watson, Diplomacy: The Dialogue between the States, p. 96.

${ }^{14}$ Michael Mallett, "Italian Renaissance Diplomacy", Diplomacy and Statecraft, Vol. 12, No. 1, (March 2001), p. 63.
} 
The Emergence and Expansion of the Permanent Diplomacy

state as an institution of the material world. Building the state as a secondary institution in the frame of Christianity transformed it into a social institution that gained its legitimization from religion and had to act in the frame of religion. Therefore, (as an effect of the feudal organizational form) this led both to the effectiveness and weakness of the state political authority holders, who had to act according to legal and moral dimensions shaped by Christianity.

The radical break of political philosophy in Italy, which depended on the separation and secularization of legitimization from its religious context, affected the whole of Europe. Thus, religion-based legitimization ceded its place to a legitimization based on the ownership or possession of authority, as distinct from its virtual active meaning. This shift also shows itself in the change of the meaning of "stato" (state) in Renaissance Italy. According to this, power or sovereignty must be evaluated not according to its legal and moral or de jure meaning, but to its de facto meaning. So, for political authority, the important thing is not the power designated by law or religion, but the power that is owned actually (realistically). ${ }^{15}$

This shift paved the way for development of the notion that the political authorities' powers extended beyond the territorial scale. According to this idea, powerful princes/governments entered into relations with less powerful princes/governments and forced them to do their bidding. While acting in this way, the only thing that limited them was the degree of their power. Religious and legal legitimization as well as restrictions and rules in this legitimization frame did not hold importance. ${ }^{16}$

Acceptance of the new political philosophy introduced the theoretical base that would secure legitimization of power

15 Machiavelli was the first author defending this new power understanding clearly. Niccolo Machiavelli, Prince, trans. Luigi Ricci, New York, The New American Library of World Literature Inc., 1952.

16 Watson, Diplomacy: The Dialogue between the States, p. 98. 
challenges between the Italian city-states and the authorities of sovereigns. Inevitably this fact affected the institutional and methodological developments of diplomacy:

Primarily, the confirmation of a political authority's legitimization was the major stimulus of the centralization phenomenon mentioned above. Thus, a political philosophy based on monism and the certainty of a political sovereign's authority, together with the socio-economic dynamics of centralization, played a significant role in the institutionalization of diplomacy.

Secondly, a political philosophy focused on the attainment of absolute power encouraged political sovereigns to try to increase their power both internally and externally of the state. Internally, this attempt was depended on settlement efforts of other centrifugal power focuses and establishing a monopolistic sovereignty over society. Externally it was dependent on introducing sovereignty to other powers as well as protecting and expanding it. ${ }^{17}$ Understanding that these efforts could not be realized by military power alone caused diplomacy to be accepted unavoidably as a methodology to secure their aims. As the importance of diplomacy increased, it became more of a daily activity. In this context, the need to ground diplomacy on a permanent base motivated the establishment of permanent diplomatic representative offices.

Thirdly, the secularization of political philosophy limited the effects of Christianity in shaping the relations between political units and drawing them into a moral and legal framework. Thus,

\footnotetext{
${ }^{17}$ Sending and accepting ambassadors started to be perceived as a sovereignty indicator. The principle that just sovereign rulers or governments can send or accept ambassadors was adopted. Queller, The Office of Ambassador in the Middle Ages, p. 11. However in the $15^{\text {th }}$ century, during the era of transition to permanent diplomacy, this principle was not accepted immediately and feudal effects continued for a time. Non-sovereign and dependent units are also known to have sent and accepted ambassadors. Anderson, The Rise of Modern Diplomacy, p. 5.
} 
The Emergence and Expansion of the Permanent Diplomacy

the vision of a universal Christian family nurtured by feudalism started to be replaced by the conflicting views of sovereign political units that were challenging each other and were not necessarily as regulated by Christianity as previously, and by conflicts between the religious and political hierarchy. Refusal of hierarchy in both theory and practice encouraged a secular, egalitarian and multilateral internal processing dynamic to take root in the centralized system. Relations within the system had a direct effect on the development of diplomacy. Diplomacy would gain importance in pursuing relations inside the system. This represented a clear break with feudal practice, and helped to promote understanding and acceptance of permanent diplomacy within the system.

\section{B) Economic Factors}

In the Middle Ages, the sovereign feudal production system predominated throughout Europe. In the $15^{\text {th }}$ century, the northern part of Italy began to experience socio-economic changes that reflected the birth of commercial capitalism. This change affected the whole social structure of the Italian city-states and favored the adoption of permanent diplomatic methods.

Above all, commercial capitalism affected the Italian citystates' understanding of foreign policy. With the emergence of commercial capitalism, these entities began to attribute a different meaning to territorial power. Countries had been measuring their power by the possession of land and military power since ancient times. According to this traditional understanding, power was dependent on territorial logic. It was held that the larger the areas under a sovereign's control, the greater their power. Not surprisingly, conquest became the central focus of foreign policy.

On the other hand, Italian city-states also started to measure their power by economic means. Only via the wealth and power that capitalism brought to these territorial "midgets" could the city-states gain greater influence in a world system that had 
hitherto confined these territories to a traditional understanding of their place in the world. Therefore, for these countries, territorial growth and influence won through military power was replaced by economic power gained through trade. Instead of military tactics, peaceful methods started being promoted. Thus, the aim of peacekeeping in foreign policy had also an important effect on the development of diplomacy.

War was contradictory to capitalist rationality because it would reduce commercial income and erode the economic wealth of countries. The long conflicts between Italian city-states during the first half of the $15^{\text {th }}$ century were effective on the expansion of this perception. ${ }^{18}$ In this context, as time passed, Italian city-states believed that the cost of wars would be less than income gained at the end of them. As a result of this, the attempts to prevent war and increase economic wealth during peace became one of the main objectives of foreign policy. These transitions in foreign policy targets were fundamental to the development of diplomacy. On the other hand the concretion of this shift was realized with the acceptance of permanent diplomacy understanding. ${ }^{19}$

Another important effect of the development of commercial capitalism was its positive repercussion on diplomatic relations as a consequence of regular and permanent commercial relations among the Italian city-states and their interaction with the outside world. On-going commercial dealings naturally influenced political affairs. Commercial relations became simultaneously a channel for political relations. Trade by its nature, opens and maintains relational instruments between parties and contributes to the development of political associations. As Arrighi emphasizes, "long-distanced trade detected by capitalist oligarchies, secured the

\footnotetext{
18 Michael Mallett, "The Northern Italian States", in Cristopher Allmand (ed.), The New Cambridge Medieval History, Vol. VII, Cambridge, Cambridge University Press, 1998, p. 549.

19 Giovanni Arrighi, Long Twentieth Century: Money, Power, and the Origins of Our Time, London, Verso, 1996, p. 69.
} 
The Emergence and Expansion of the Permanent Diplomacy

existing basis and compensated institutional structure that diplomatic relations would set on". ${ }^{20}$

Italian merchants were continuously gathering information about the countries with which they had interactions. The information was not limited to economic indicators. On the contrary, it tended to have an additional political character. ${ }^{21}$ This had an important effect on the emergence of permanent diplomacy. Over time, the need to organize information-gathering mechanisms motivated the establishment of permanent diplomatic offices.

The importance of trade among Italian city-states' economies also had its effects on the organization of public administration. If a socio-economic substructure is considered as the main determinant on emerging, shifting and removing political institutes, this fact can be understood more clearly. The power of the city governors was dependent on their commercial wealth. As seen in Venice, and in parts of these cities, the oligarchic administrations of families that were controlling trade were being maintained. Therefore, the importance that was given to the control of trade among states had a central role on the functions and the institutional development of the bureaucratic structure. Public administration of trade was seen as essential and the most prominent aspect of this desire was the emergence of permanent diplomatic representative offices. Acceptance of the concept of permanent diplomacy has consistently promoted the emergence of new organizations within central bureaucracy.

The trade-dependent economies of the Italian city-states were also important for the emergence of the class base of the persons who were conducting diplomatic activities. An emerging bourgeoisie class started to control diplomatic affairs and merchants became the most important actors in diplomatic interactions. Once the role of commercial relations on the

${ }^{20}$ Ibid., p. 71

${ }^{21}$ Watson, Diplomacy: The Dialogue between the States, s. 96. 
development of political relations is considered, it can be said that this situation was not surprising. Given its negotiation-based nature, trade overlaps with the logic of diplomacy. Italian merchants had high-level negotiation skills, and therefore they knew that words were generally more effective than swords. ${ }^{22}$

In some instances diplomatic affairs were organized and conducted by merchants who could afford to maintain embassies with their own initiatives. Mostly, the costs of embassies were borne by merchants and embassies tried to gain commercial and legal advantages and rights for the merchant groups that they were representing. ${ }^{23}$ This fact is the most apparent example of the relation between trade and diplomacy.

\section{C) Cultural Factors}

In Italy, in relation to the acceptance of permanent diplomacy, the common culture of societies living in this geography had an important effect as well. As in Ancient Greece, Italian city-states had common religious beliefs, language and traditions. This social communication eased the development of diplomatic ties among them.

A shared culture helped to ease permanent embassies' adaptation to the social and political structure of the countries they were sent to. Common language had a particularly positive function in this process, itself grounded in the need for enhanced communication and exchange. ${ }^{24}$

Another important effect of cultural partnership is that it facilitated interaction between Italian city-states. Any new phenomena that emerged in one state could reach the others. This

\footnotetext{
22 Mattingly, Renaissance Diplomacy, p. 62.

23 Anderson, The Rise of Modern Diplomacy, p. 4.

${ }^{24}$ Keith Hamilton and Richard Langhorne, The Practice of Diplomacy; It's Evolution, Theory and Administration, London and New York, Routledge, 1995, p. 31.
} 
The Emergence and Expansion of the Permanent Diplomacy

situation also enabled the city-states to readily learn about and adopt diplomatic novelties from each other. These transfers played a key role in prompting and nurturing the innovation of permanent diplomacy.

Beyond this, European societies' similar cultural structures had an important effect on the rapid expansion of permanent diplomatic understanding. This was achieved in Central and Western Europe within a century. Similar cultural structures eased communication and interaction between societies. Due to the growth of diplomacy and the acceptance of common diplomatic rules (and traditions), the emergence of a common "diplomatic culture" became possible.

Another cultural factor that made Italy the pioneer of permanent diplomacy was the fact that, in the $15^{\text {th }}$ century, the region was culturally the most developed part of Europe. It had survived the cultural deterioration of the Middle Ages better than other parts of Europe. In Italy, the high level of education and culture of the elites had a positive effect on the development of diplomacy. Well-educated elites having embraced more sophisticated diplomatic procedures had obtained the ideal maturity for diplomacy and the intellectual level required. When considered that governors with high intellectual capacities could perform peaceful methods for the protection of their territorial interests, the growing importance of diplomacy in general, and the lodgment of permanent diplomacy in particular, can be understood more easily. Moreover, having relatively more educated people is also important for the establishment of a bureaucratic structure to conduct foreign policy. Consequently, a structure skillful enough to conduct diplomatic affairs in permanent embassies and capable of organizing these activities in the Capital had emerged. ${ }^{25}$

Additionally, in becoming a cultural and intellectual center, this region opened the way for subjects of other societies such as students, priests, artists and princes to come to Italy from different

${ }^{25}$ Ibid., p. 30. 
parts of Europe. ${ }^{26}$ This made for Italy to have the potential to affect the rest of Europe in the Middle Ages, and was another factor for the rapid expansion of permanent diplomacy in Europe.

The emergence of the European renaissance in this region can be regarded as the natural result of cultural maturity. The renaissance, with its beginnings in the $14^{\text {th }}$ century, was a challenge against the form and understanding of the Middle Ages. It contains a radical shift of man's view of nature and his position in the world. Loyalty to the doctrines of the Middle Ages was replaced by ideas searching for improvement. This shift of thought had been effective on a significant range of fields from art to politics. Accordingly, attempts to introduce a new point of view to diplomacy were closely related with the renaissance. Mattingly relates the new diplomacy understanding symbolized by permanent diplomacy to the renaissance spirit. He also claims that the renaissance was the driver of permanent diplomacy. ${ }^{27}$

\section{D) Religious Factors}

Christianity, combined with feudalism, was one of the most important factors that shaped Medieval Europe. It also played a crucial role in forming the diplomatic relations between political units. However, the questioning of this role in Italy and the decrease of Christianity's influence over the political area also played a significant role in the emergence of permanent diplomacy.

Christian understanding of the world during the Medieval Era was based on a sharp distinction between believers and nonbelievers. This view was theorized by St. Augustine who called for universality in the Christian world. ${ }^{28}$ Accordingly, the entire Christian world was one body and a whole country/republic

${ }^{26}$ Michael Mallett, "Italian Renaissance Diplomacy", p. 63.

${ }^{27}$ Mattingly, Renaissance Diplomacy, p. 55.

28 A. Nuri Yurdusev, "Uluslararasi Ilişkeiler Öncesi”, in Atilla Eralp (ed.), Devlet Sistem Kimlik, 2. ed., İstanbul, İletişim Yayınları, 1997, pp. 36-37. 
The Emergence and Expansion of the Permanent Diplomacy

(Respublica Christiana). Atop of this structure was the Church representing God. This understanding was indicative of the context of relations between political units and attempts aiming to place them into the Church's legitimization. The basic relations between political units (for instance in times of war) were evaluated according to limits legitimized by the religion.

This restrictive notion of religion had positive effects on the emergence of diplomacy. Watson emphasizes that the roots of permanent diplomacy are to be found in ad hoc diplomatic relations developed by the view of "Respublica Christiana". ${ }^{29} \mathrm{He}$ observed that a continuity of diplomatic relations emerged in this framework and diplomacy gained a legitimate historical basis for its future development in Europe.

At the same time, this religious dimension was important for the establishment of an inter-state system in Europe, as despite all challenges and conflicts, these political units conceived themselves as a part of the great Christian family. ${ }^{30}$ Thus, the existence of a collective political identity among the various political units encouraged the emergence of a system where relations were valued. This historical legacy, despite the decreasing role of religion with the beginning of the modernization process, still continues to play a role partly and indirectly in European affairs.

Another effect of Christianity was its role in the development of international law by affecting regulations and rules for international interactions. Although the religious aspect lost its importance over time in parallel to secularization, Christianity made great contributions to the institutionalization of rules among countries and the conduct of diplomacy in this context. In fact one of the three sources of international law was Christianity in this period. The other two sources were the Roman and German laws. ${ }^{31}$

\footnotetext{
${ }^{29}$ Watson, Diplomacy: The Dialogue between States, p. 97.

${ }^{30}$ Mattingly, Renaissance Diplomacy, pp. 18-20.

${ }^{31}$ Ibid., p. 24.
} 
Another important effect of Christianity on diplomacy was the Papacy's power to affect secular dynamics and prevent the emergence of a "universalist" great power. As mentioned above, the emergence of a "universalist" power had prevented the birth of a multi-actor system dependent on equality. However, even the rise of the Holy Roman Empire was restrained by the efforts of the Papacy.

\section{E) Historical Factors}

Although the transition to permanent diplomacy in Italy was realized with institutional and methodological shifts in diplomacy, accommodations of ad hoc terms also affected this development. In fact, experiments in diplomacy, especially during the Roman/Byzantine period had important effects on the diplomatic understanding of the Italian city-states.

The region in Western and Central Europe where the Roman/Byzantine effect could be seen more noticeably after the dissolution of Western Roman Empire and during the long domination of the Byzantine Empire was Italy. Furthermore, the Italian peninsula was also the political, economic and cultural center of the Roman Empire. In addition, from the $9^{\text {th }}$ century until its dissolution in the $15^{\text {th }}$ century, the Byzantine Empire had overwhelmingly influenced Italian cultural, economic and political life. Despite the problems or battles between them, the importance of Eastern trade for the Northern Italian city-states was the main factor preserving the continuity of their relations. ${ }^{32}$

For centuries, particularly through the isolation period of Western and Central Europe, primarily Venice and all other Italian city-states were the main actors of the West in contact with the

\footnotetext{
${ }^{32}$ For an important work on Venice and Byzantine relations, Donald M. Nicol, Byzantium and Venice: A Study in Diplomatic and Cultural Relations, 3. ed., Cambridge, Cambridge University Press, 1994.
} 
The Emergence and Expansion of the Permanent Diplomacy

East. Eastern political and cultural accommodation was transported to the West via the Italian city-states. Italy as a bridge between East and West was the place where the Eastern effects were at the most noticeable level. One of the dimensions/channels of this effect was diplomacy. When this effect is analyzed the main points can be highlighted as follows:

Firstly, during the decline of the Byzantine Empire that began during the $11^{\text {th }}$ century, the Empire attached great importance to diplomacy in order to preserve its territorial sovereignty and integrity. Therefore, due to its important diplomatic actor status, Venice became the country that was most influenced by developments within the Byzantine Empire. As Nicholson said, Venice was the first Western power understanding and accepting the Byzantine diplomatic theory. ${ }^{33}$

Venice observed closely Byzantine diplomacy methods, such as creating conflicts between countries, benefiting from them and making alliances. Moreover, many times Venice had become a part of these processes. In time, the Genoese and other Italian citystates established relations with the Byzantine Empire and accordingly, the Byzantine effect became more apparent in Italy. The Italian city-states employed these methods effectively, both in the ad hoc period before the $15^{\text {th }}$ century and in the permanent diplomacy period that followed.

One of the most important effects of Byzantine diplomacy on the advent of permanent diplomacy was the "balio" institution. ${ }^{34}$ The "Balio" was an officer who was appointed from the center and had political, administrative and legal authority over Venetian citizens as the head of a Venetian trade colony. ${ }^{35}$ Similar trade-

\footnotetext{
${ }^{33}$ Nicolson, The Evolution of Diplomatic Method, p. 27.

34 When the "balio" institute appeared first is not clear. However, in an agreement of 18 June 1265 between the Byzantine Empire and Venice, clear and detailed regulations were adopted on its establishment and status. Nicol, Byzantium and Venice, p. 181.

35 This institution as a legacy to the Ottoman Empire, even after the conquest of Istanbul remained important as a demonstration of the value of the Eastern
} 
based institutions with this feature were established in the $12^{\text {th }}$ century to afford the Italian city-state consulates at the Eastern harbors. However, Mattingly identified a different role for the "balio" in Istanbul, where unlike the other consulates it performed a continuous diplomatic function and asserts that, it should be seen as premise of permanent Venetian embassies, which were to be established in future. ${ }^{36}$ In fact, generally all these consulates and particularly the consulate in Istanbul were prototypes of permanent embassies and important models for the Italian citystates during the process of transition to permanent diplomacy.

Another indicator of diplomatic ties between Venice and the Byzantine Empire is the regularity of diplomatic correspondences and their protection. Under the Roman/Byzantine bureaucratic tradition, Venetians built a state archive and kept all their correspondences with other states and consulates. This regular archive contains files from 833 to 1797 when Napoleon abolished the political status of the Venice Republic. ${ }^{37}$

The Byzantine Empire contributed also to the Renaissance with its promotion of Ancient Greek thought and restoration of aspects of its culture. The transition of political philosophy and therefore its effects on the conception of Renaissance diplomacy can be understood more clearly through the centuries of continuous relations with the Byzantine Empire.

The legacy of the ad hoc period also contributed to the emergence of permanent diplomacy in northern Italy. The multiactor structure of feudalism, universalism of Christianity and the regulator effect of the Church had a crucial role in the ad hoc period. Despite the fact that feudalism depends on a certain hierarchy, it secured the emergence of a multi-actor structure. With

trade for the Italian city-states and the role of the economic factors on passage to permanent diplomacy. Tayyip Gökbilgin, "Konsolos", İlam Ansiklopedisi, Vol. VI, p. 836.

${ }^{36}$ Mattingly, Renaissance Diplomacy, p. 68.

${ }^{37}$ Nicolson, The Evolution of Diplomatic Method, p. 27. 
The Emergence and Expansion of the Permanent Diplomacy

the stability in Europe after the $11^{\text {th }}$ century, relations between political actors had become more regular. As a result of this, during the $13^{\text {th }}$ and $14^{\text {th }}$ centuries diplomatic relations and activities increased. Beyond this, diplomatic relations developed not only between political units but also between economic, cultural, religious and social units. In time, diplomatic affairs were seen not just between princes and independent cities, but also between feudal lords, trade unions and universities. According to Mattingly these actors were sending "semi-diplomatic representatives" to each other. ${ }^{38}$ Thus, multilateralism, which is very important for the practice of diplomacy, could be seen in Medieval Europe during the pre-permanent diplomatic term. Additionally the existence of many actors in the diplomatic process is evidence for the scope and intensity of this diplomacy.

The intensity of this ad hoc period was effective on the emergence of new notions, rules and institutions in the diplomatic area that were shaped by the Christian, Roman and German traditions in which European civilization is rooted. In fact, basic notions and principles such as diplomatic immunity, the right to send ambassadors and diplomatic protocol were accepted practices in Medieval Europe before the $15^{\text {th }}$ century. The perceptions and applications of these institutions, principles and notions are analyzed below.

\section{The Emergence and Development of the Permanent Diplomacy Approach}

\section{A) The Function of Diplomacy before Permanent Diplomacy}

Europe started to free itself from the instability of the $4^{\text {th }}$ and the $5^{\text {th }}$ centuries with the institutionalization of Feudalism in the $9^{\text {th }}$ century. This medieval character also had implications for the

\footnotetext{
${ }^{38}$ Mattingly, Renaissance Diplomacy, p. 27.
} 
development of diplomacy. Prior to the emergence of the permanent diplomacy understanding, the medieval period fostered significant continuity and legalization of diplomacy.

The most important phenomenon of the diplomatic function as emphasized above was the "Respublica Christiana" that created a diplomatic area/system between diplomatic actors. This commonality fostered the increase, stability and regularity of diplomatic activities.

Law was a very important determinant for the emergence and the functions of this area/system. During the Middle Ages, as mentioned above, the legal sources of social life in general and diplomacy in particular had been Church, Roman and Feudal law. Church and Roman Law were more influential on diplomacy due to their universalist structures and this was generally applied to the rules of diplomacy during the ad hoc term.

From the $11^{\text {th }}$ century, Church jurists had begun to study relations between states. Issues like the sanctity of treaties, peacekeeping, rights of parties and reducing the negative effects of wars were researched. ${ }^{39}$ By the end of the Middle Ages, the Church lost its effectiveness and civil law, framed in Roman Law, gained in importance. Diplomacy too became a more secular and rational discipline. ${ }^{40}$ In the context of its chivalry philosophy, Feudal Law was an important legal source on subjects such as the treatment of messengers, slaves and non-belligerents, and was also concerned about the area of diplomacy. ${ }^{41}$

It can be seen that in addition to its role in the legal system, the Church was also an actor in the diplomatic system of Europe. In medieval times, Papal officers and diplomatic representatives at the Papacy were the most important sources of information and

\footnotetext{
${ }^{39}$ Ibid., p. 22.

${ }^{40}$ Hamilton and Langhorne, The Practice of Diplomacy, p. 23.

${ }^{41}$ Idem.
} 
The Emergence and Expansion of the Permanent Diplomacy

communication $^{42}$ In other words, the institution of the Church was an instrument for pursuing diplomacy and communication between diplomatic actors.

In addition, the diplomatic activity during the power conflict between the Church and the Holy Roman Empire, and the term of disunion in the Papacy known as the "Great Schism" (13781417) made the Church an active diplomatic actor. This fact, despite its weakened power and role in society, led to noticeable increases in Church-led diplomatic activity around Europe.

Prior to the transition to permanent diplomacy, another important development was the new characteristics that the embassy phenomenon had gained. In the Middle Ages all diplomatic representatives were called "legati" (legatus). The word "ambaxiator" of the Late Middle Ages was synonymous with the word "legati" of the Roman Empire. This synonymy had disappeared over time and "legati" started to define the Church representatives. Thus, the word "ambaxiator" took its place in diplomatic literature to describe today's ambassador. ${ }^{44}$

The usage of "ambaxiator" is important also for the hierarchical status of the diplomatic representative. It was used for the highest-level diplomatic representatives. For the lower diplomatic representatives, the terms "nuncio" and "procurator" were used. The emergence of the term "nuncio" goes to back to the beginning of the Middle Ages ${ }^{45}$ when "nuncio"s were the carriers of letters. However, it is useful to note that unlike the previous embassies, "nuncio"s tended to transport their messages orally. Hamilton and Langhorne describe them as "live letters" 46 and they can be said to have brought a new dimension to the diplomatic

\footnotetext{
${ }^{42}$ Watson, Diplomacy: The Dialogue between States, p. 96.

43 David Nicholas, The Transformation of Europe 1300-1600, London, Arnold Publishers, 1999, pp. 128-129.

${ }_{44}$ Mattingly, Renaissance Diplomacy, p. 29.

45 Donald E. Queller, "Thirteenth Century Diplomatic Envoys: Nuncii and Procuratores", Speculum, Vol. 35, No. 2, (April 1960), p. 196.

${ }^{46}$ Hamilton and Langhorne, The Practice of Diplomacy, p. 24.
} 
language. Nevertheless, "nuncio"s had limited authorization. They were allowed to transmit the message given to them but not to negotiate. The limitation of their capabilities and tasks had been related to the limitations over diplomatic actors until the end of the Middle Ages. ${ }^{47}$ However, when diplomatic activities made a great step quantitatively and qualitatively, "nuncio"s became insufficient to the conduct of diplomatic relations.

The increase of diplomatic relations in the late Medieval period and the transformation of the subjects of diplomatic relations into a more complex status obliged the diplomatic representatives, engaged with diplomatic affairs, to conform to these new circumstances. Instead of "nuncio"s that had held their status almost since the Merovingian period, another kind of diplomatic representative took their position. These new diplomatic representatives were called "procurator"s. Despite the fact that they were not diplomatic representatives, during the $11^{\text {th }}$ century they became Popes' representatives authorized to sign special agreements. ${ }^{48}$

Beginning with the $13^{\text {th }}$ century, "procurator"s began to be sent instead of "nuncio"s and they had a much stronger diplomatic representation status. They had authorization to negotiate and this was the result of the will of actors to use diplomacy more effectively. Relations between remote political units began to develop and it became difficult to have effective diplomacy solely through "nuncio"s because of their limited representation capability.

The increase of "procurator"s representation power and authorization was the last important milestone of the transition to permanent diplomacy. This kind of embassy had two important effects on the emergence of permanent diplomacy:

Primarily, "procurator"s negotiation ability strengthened the diplomatic activities of the ambassadors. Their representative

${ }^{47}$ Ibid., p. 25.

48 Ibid., p. 26. 
The Emergence and Expansion of the Permanent Diplomacy

functions extended beyond conveying messages to the conduct of longer and continuous diplomatic processes.

Secondly, "procurator"s gained prestige and effectiveness because of their representational authority. In this way diplomatic representation was placed on a professional footing.

\section{B) Transition to Permanent Diplomacy}

The political and economic rivalries between Italian citystates increased during the second half of the $13^{\text {th }}$ century. In addition, Italy, under the leadership of France, became a region to which European powers paid maximum attention. As a result of this development in Italy, ad hoc diplomacy became to be used more frequently and diplomatic ties obtained permanency. Parallel to this, the empowered economic relations between diplomatic actors also led to the expansion of consulates. Semi-diplomatic institutions like consulates and trade representatives rapidly became widespread in Central and Northern Italy, between 1380 and $1450 .^{49}$

One natural consequence of this situation was the need to maintain diplomatic representation upon a more permanent basis. This led to the establishment of permanent diplomatic representatives. It is not certain when and where the first diplomatic representation was founded. Mattingly, argues that the first permanent embassy was founded by the Italian city-state of Montua to the Princedom of Bavaria as early as $1341 .^{50}$ Mattingly also argues that the first installment of permanent embassies among Italian city-states took place between the years 1375- 1379 in Milan and Montua. However, this experience did not last long and neither side appointed permanent ambassadors after $1379 .^{51}$ Mattingly also draws attention to the fact that there were

49 Mattingly, Renaissance Diplomacy, p. 69.

${ }^{50}$ Ibid., p. 71.

${ }^{51}$ Ibid., pp. $71-72$ 
permanent diplomatic ties between the Duchy of Milan and Hungary during the period $1425-1432 .^{52}$ Nonetheless, this experience also ceased after a certain period.

Anderson argues that the first permanent embassy was established by Nicodemus, who was sent by Milan to Florence in 1446 to serve for more than 20 years. ${ }^{53}$ This example was followed by the embassies of Naples, Geneva, Rome and Venice in the following decade. ${ }^{54}$ The most suitable date for the transition to permanent diplomacy was the year 1460. In this year, the ambassador sent by the Savoy Duchy to Rome was clearly defined as "permanent" ("orator et ambaxiator continuus et procurator").

\section{C) The Expansion of Permanent Diplomacy in Europe}

This new approach to diplomacy that emerged in Italy soon became widespread in Western and Central Europe. The technical adoption of permanent diplomacy was principally motivated by its functionality being gradually understood by political actors.

During the $15^{\text {th }}$ century, the Italian city-states began to found permanent diplomatic representation offices outside of Italy for political and economic reasons. Permanent embassies were opened in Spain, England, France and Austria. ${ }^{56}$ This expansion outside of Italy became known as the second wave.

Within this era corresponding to the beginning of the $16^{\text {th }}$ century, the powers in Central and Western Europe started to practice the concept of permanent diplomacy. Western and Central European powers started to open permanent embassies both in Italian-states and among each other. This empowered diplomatic

${ }^{52}$ Ibid., pp. $76-77$.

${ }^{53}$ Anderson, The Rise of Modern Diplomacy, p. 7.

${ }^{54}$ Idem.

55 Ibid., p. 6.

${ }^{56}$ Hamilton and Langhorne, The Practice of Diplomacy, p. 36. 
The Emergence and Expansion of the Permanent Diplomacy

ties to an unprecedented extent and led to significant development of the institutional and methodological framework of diplomacy. ${ }^{57}$

Interestingly, the second wave was not uniformly comprehended by the various European powers. At the beginning of the $16^{\text {th }}$ century, France, contrary to the policies of other states, refrained from opening permanent embassies as she was the most powerful state of Europe at the time. The only permanent embassy outside France until the second quarter of the 16th Century was the one in Austria that was opened in 1509. The defeat of François I in 1525 by the Emperor of Austria, Charles V, in the Pavia War caused France to step up its efforts to invigorate its diplomacy and to find allies. Under duress, France moved to adopt the concept of permanent diplomacy and embassies, and the number of permanent embassies rose from 1 in 1515 to 10 by the end of François' reign. ${ }^{58}$

Despite this hesitation in the transformation to permanent diplomacy, France rapidly adopted the permanent style modeled by the Italian city-states. The $15^{\text {th }}$ and $16^{\text {th }}$ centuries were a period in which the concept of permanent diplomacy was shaped by Italy. Thereafter, from the $17^{\text {th }}$ until the $20^{\text {th }}$ century when a "new diplomacy" emerged, it was shaped by France. ${ }^{59}$

The impact of France shows itself in all aspects of the institutional and methodological dimensions of diplomacy. To cite an example from an institutional perspective, the concept of a Ministry of Foreign Affairs was first founded and professionalized in France. From the methodological perspective, French had

\footnotetext{
${ }^{57}$ It's not possible to say that permanent diplomatic understanding was accepted willingly by all the great powers. By its nature, permanent diplomacy bears factors like dependency, sovereign equality, equal or nearly equal protocol applications, etc. Furthermore, it was not able to prevent the emergence of important problems between parties even after centuries of this new understanding being accepted.

58 Anderson, The Rise of Modern Diplomacy, p. 9.

${ }^{59}$ Nicolson, The Evolution of Diplomatic Method, pp. 48-71.
} 
become the language of diplomacy and diplomatic negotiations were conducted according to the French system.

It is clear that there was a flourishing of the diplomatic system with the adoption of permanent diplomacy in the $16^{\text {th }}$ century. In the Scandinavian countries that existed outside this diplomatic system and in peripheral countries like Scotland, Portugal, Poland and Russia, the method of permanent diplomacy would not be adopted until the end of the $17^{\text {th }}$ and the beginning of the $18^{\text {th }}$ centuries. ${ }^{60}$ In Russia for example, the first permanent appointment similar to an ambassador was made in 1673, during the reign of the pioneer of Russian modernization, Peter I. ${ }^{61}$

The adoption of the method of permanent diplomacy in the rest of Europe took place with the beginning of the third wave that emerged in the beginning of the $18^{\text {th }}$ century. After this, it was possible to talk about a more comprehensive diplomatic system or area. In the $19^{\text {th }}$ century, permanent diplomacy had expanded to the rest of the world as a fourth wave and the Ottoman Empire was its first participant.

\section{Conclusion}

Diplomacy was born in Ancient Mesopotamia where an interstate system of an ad hoc character existed for thousands of years. This type of diplomacy was limited by time and there was a noticeable lack of permanent diplomatic representation. Various types of political, economic, cultural and military factors emerged during the $14^{\text {th }}$ century that provided for the adoption of permanent diplomatic comprehension instead of ad hoc diplomacy. This new era in the transition from a feudal to a statist Europe was important not only in terms of the birth of the modern world but also in terms of the rise of modern diplomacy.

${ }^{60}$ Anderson, The Rise of Modern Diplomacy, pp. 27-28.

${ }^{61}$ Ibid., pp. 69-70. 
The Emergence and Expansion of the Permanent Diplomacy

The symbol of this process was the Renaissance period that had its birthplace in Italy. Italian city-states were the first to become members of a modern system that contributed to the improvement of diplomacy. The lack of political unity in Italy led to the emergence of a regional, interstate sub-system. The resulting social and political transformation in Italy had several implications for the comprehension and practice of diplomacy. Thus, during this transition, diplomacy matured to require a permanent form.

Initially, the success of permanent diplomacy spread from Italy to Western and Central Europe. Moreover, the great powers such as France, the Holy Roman Empire and the British Empire soon adopted this concept. This development paved the way for the expansion of relations between European states more than ever before. From the $16^{\text {th }}$ century onwards, the new diplomacy understanding was shaped by the dominance of France in Europe. French institutions and methods became the model for diplomacy. By the $19^{\text {th }}$ century, all European countries applied permanent diplomatic practices in some shape or form. This in turn has played an important role in the formation of the international system and the practice. 